\title{
Hook selectivity of the Pacu Piaractus mesopotamicus (Holmberg, 1887) in the Pantanal, the state of Mato Grosso do Sul, Brazil
}

\author{
Peixer J.* and Petrere Jr., M.* \\ Departamento de Ecologia, Universidade Estadual Paulista Júlio de Mesquita Filho - UNESP, \\ Avenida 24 A, n. 1515, CP 199, CEP 13506-900, Rio Claro, SP, Brazil \\ *e-mail: janicepeixer@yahoo.com.br, mpetrere@rc.unesp.br
}

Received May 11, 2005 - Accepted December 15, 2005 - Distributed May 31, 2007

(With 3 figures)

\begin{abstract}
The Pacu Piaractus mesopotamicus is the most captured fish species in the Pantanal, Mato Grosso do Sul State, and since 1994, its maximum sustainable yield had already been exceeded. Its capture is carried out only by hooks, as mesh gears are forbidden either for professional or for recreational fishing. The aim of this study was to determine selectivity for different hook sizes used in P. mesopotamicus fishing and to verify which sizes capture only adults. Data were collected in the rivers Miranda, Aquidauana, and Vermelho, in January, March, and April 2002. Six longlines with eight hook sizes were used and we adopted the hook opening as a measure related to selectivity. Different hooks captured individuals of the same length and their medians were similar, evidencing the great overlap among sizes. Regression results showed no significant relationship between $\ln \left[\frac{c_{2}(l)}{c_{1}(l)}\right]$ and total length of captured individuals. In addition, the Kolmogorov-Smirnov test also did not detect significant differences in the size of captured fish. Several hypotheses, such as the selectivity models, shape of selection curves, scarcity of large fishes, and behavior are used in order to explain the absence of hook selectivity for this species. Size of recruitment for this gear was $28 \mathrm{~cm}$ of total length, when individuals are still immature.
\end{abstract}

Keywords: hook selectivity, Pacu, Piaractus mesopotamicus, Pantanal, Brazil.

\section{A seletividade do anzol para o Pacu Piaractus mesopotamicus (Holmberg, 1887) no Pantanal do Mato Grosso do Sul, Brasil}

\begin{abstract}
Resumo
Desde 1994, o pacu Piaractus mesopotamicus, é a principal espécie nas capturas comerciais e esportivas no Pantanal sul-matogrossense, e seu rendimento máximo sustentável já foi ultrapassado. Sua captura só é permitida por anzóis, para as duas pescarias acima, visto que as artes de emalhe são proibidas na região. O objetivo deste estudo foi o de determinar a seletividade para diferentes tamanhos de anzóis usados na captura do pacu e verificar a partir de qual tamanho de anzol somente os adultos são capturados. Para tal, foram realizadas pescarias nos rios Miranda, Aquidauana e Vermelho, nos meses de janeiro, março e abril de 2002. Seis espinhéis contendo 8 tamanhos diferentes de anzóis foram empregados. A abertura do anzol foi adotada para expressar sua seletividade. Diferentes anzóis capturaram indivíduos de mesmo comprimento, e suas medianas foram similares, evidenciando a grande sobreposição dos tamanhos capturados. As regressões entre $\ln \left[\frac{c_{2}(l)}{c_{1}(l)}\right]$ e $l$ não foram significativas. O teste de Kolmogorov-Smirnov também não detectou diferenças significativas nos tamanhos dos peixes capturados por diferentes anzóis. Várias hipóteses são levantadas para explicar a ausência de seletividade dessa amplitude de tamanhos de anzóis para a espécie. O recrutamento para a pesca, porém ocorre aos $28 \mathrm{~cm}$ de comprimento total, quando os indivíduos ainda estão imaturos.
\end{abstract}

Palavras-chave: seletividade por anzol, Pacu, Piaractus mesopotamicus, Pantanal, Brasil.

\section{Introduction}

The pacu Piaractus mesopotamicus is the most captured fish in the Pantanal, in the State of Mato Grosso do Sul, since 1994 (Catella, 2001). According to this author, the species accounted for $1 / 3$ of the total production between 1994 and 1999, and 96\% of the fishing effort on the species came from recreational fishing. Maximum sustainable yield for this fishing had already been exceeded in the High Paraguay River Basin in the State of Mato Grosso do Sul (MSY = 437 t/year for a corresponding fishing effort $\mathrm{f}_{\mathrm{MSY}}=146,000$ fishers $\mathrm{x}$ fish- 
ing days; (Catella, 2001). In addition, according to the author, a total of $231 \mathrm{t}$ of this species was caught in 1998 , with a fishing effort of 308,000 fishers $\mathbf{x}$ fishing days. Therefore, a fishing effort twice more than the $\mathrm{f}_{\mathrm{MSY}}$, captured approximately half of the value of the maximum sustainable yield. Vaz (2001) found similar results for this species in the North Pantanal, in the State of Mato Grosso, and concluded that the fishing for this species is close to its MSY, with an annual survival rate of $17.6 \%$.

In the Pantanal of the State of Mato Grosso do Sul, net fishing it is not allowed, for both professional and recreational fishing. Castnet is the only gear allowed for professional fishers, specifically to capture baits, with a maximum height of $2 \mathrm{~m}$, minimum mesh size of $20 \mathrm{~mm}$, and maximum of $50 \mathrm{~mm}$.

In order to guarantee that a given sample is representative, gear selectivity must be determined. If the hook selectivity curve is known, i.e., the relationship between the relative frequency of retention and the individual length, the error caused by escape can be corrected. Thus, the real frequency distribution of individual length in a population could be determined (Rodrigues et al., 1988). However, the typical scarcity of large fishes in commercial fishing makes it difficult to estimate the curve properly (Millar, 1992).

Selectivity studies also make it possible to know from which size a fish species is susceptible to a given fishing gear, as well as its average and maximum capture sizes. Moreover, adoption of a minimum capture size has been an action adopted in fishing management aiming to protect young individuals, maintain breeding stocks, and control capture sizes. For the effective success of this action, gear selectivity must be known, i.e., the retention probability of a fish of length "L" for each hook size. From this information, more appropriate sizes could be adopted in order to avoid capture of juveniles that may not survive after releasing due to stress or scratches caused by the apparatus.
Thus, the aim of this study was to determine selectivity for different hook sizes used in pacu fishing and to identify the sizes that capture only adults, for an adequate management of the species, the most sought in Pantanal and already overexploited (Vaz, 2001, Peixer, 2003).

\section{Materials and Methods}

Data were collected in the rivers Miranda, Aquidauana, and Vermelho. These rivers belong to the Miranda River basin, which is a tributary of the Paraguay River, the main river of the Pantanal (Figure 1).

The first step of the research was to verify the hook types most used by the professional and recreational fishers in the region in order to determine which sizes would be tested in our experiments. Thirty professional and 30 recreational fishers were interviewed in the municipality of Aquidauana. During the interviews, their hooks were measured to avoid errors, as different names are used for the same hook size. Afterwards, we identified the most frequent hook sizes and selected eight of them. In the interviews we also asked about the baits used to capture Pacu.

The first sample was collected in January 2002, in the River Miranda, municipality of Bonito, and another two samples were carried out in March and April 2002, lasting 15 days each. Hooks containing baits were examined at regular intervals (mean of 20 minutes) in order to remove hooked fishes and replace baits. Total length $(\mathrm{cm})$, standard length $(\mathrm{cm})$, and total weight $(\mathrm{kg})$ of captured fishes in each hook size were measured.

Six longlines sets containing eight hook sizes were used: $6 / 0,6 / 0,4 / 0,5 / 0,6 / 0,8 / 0,5$, and 4/0. These names are used by the hook manufacturers, but are not clear. Different hook sizes and shapes receive the same name, as in the cases of $6 / 0$ and $4 / 0$. Thus, we decided to number the hooks in increasing order of opening width according to Figure 2. All hooks were MUSTAD ${ }^{\circledR}$, the most used

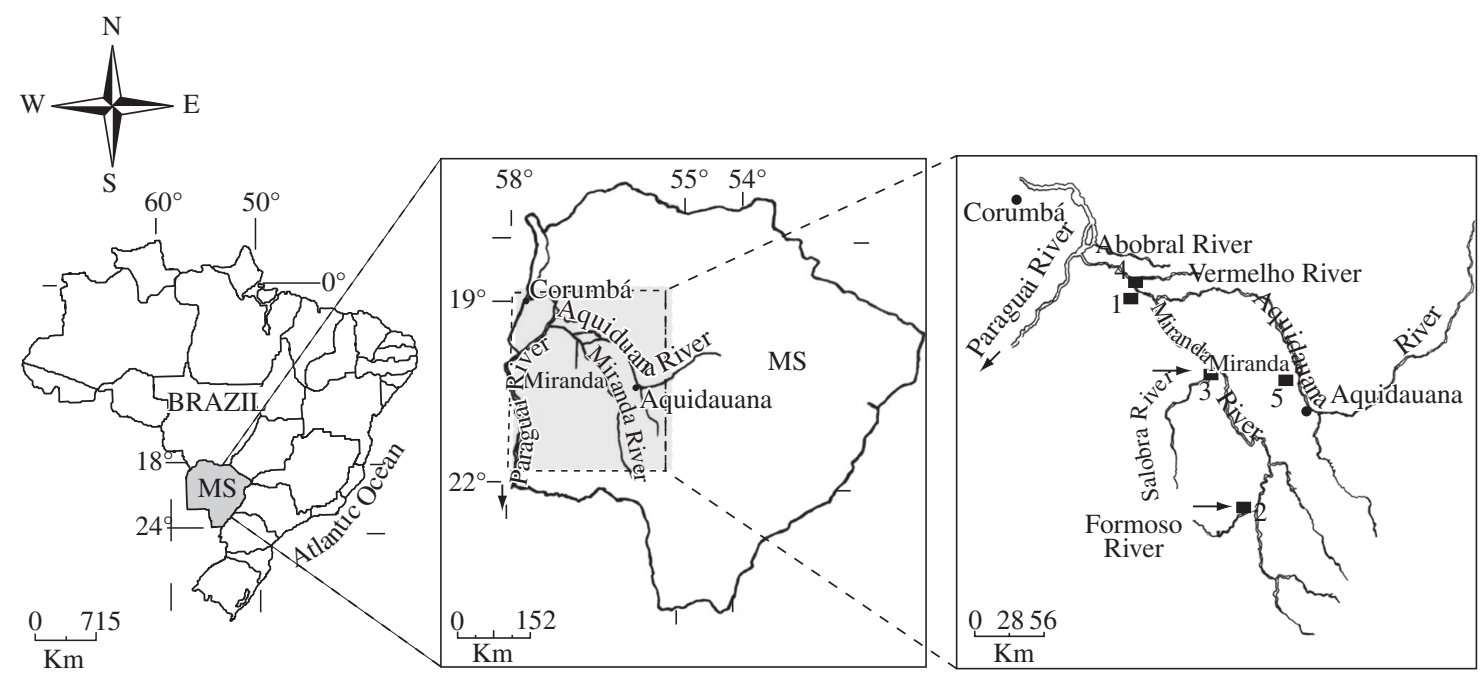

Figure 1. Sub-basin of the River Miranda with the fishing sites indicated by arrows. 
brand among fishers. The hook types are indicated in Figure 2 and their values shown in Table 1. The measure taken for hook selectivity was the hook opening.

Distance between hooks in the longlines varied from $60 \mathrm{~cm}$ to $1.5 \mathrm{~m}$, depending on river width, thus they varied from 20 to $30 \mathrm{~m}$ in length. Longlines were attached to tree trunks or shrubs at the river margins and weights were used to sink them. Each longline was composed of 16 hooks, two of each size, arranged in increasing order, and identified according to their order. Baits were placed at random and varied in size. Main baits used were local wild fruits (Pouteria glomerata, Psidium guajava, and Genipa americana), crabs (Dilocarcinus pagei), and missô (a mass made of rice and soy beans).

Hook selectivity was based on the model developed for gillnets, taking the hook opening, i.e. the perpendicular distance of the cape as the critical dimension corresponding to the net size (Pope et al., 1975; Hamley, 1975). The method used was originally developed by Holt (1963) and later adapted by Gulland (1969). This method serves to determine selectivity curve parameters through experimental fishing, using hooks of different sizes. Its assumption is that for a certain hook pair, the aperture of which differ slightly in size, selectivity curves for each hook are approximately normal and with the same variance. Moreover, it is expected that the optimum capture size, which is the mean or mode of the normal curve, be
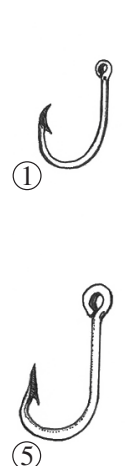

(5)
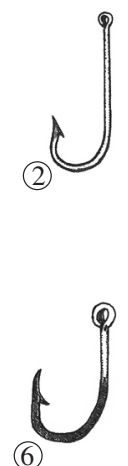

(6)

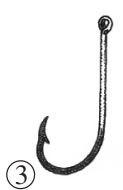

(4)


Figure 2. Hooks tested in the experiment. $1(6 / 0), 2(6 / 0)$, $3(4 / 0), 4(5 / 0), 5(6 / 0), 6(8 / 0), 7$ (5), 8 (4/0).

Table 1. Hook measurements (mm). N: number of hooks.

\begin{tabular}{llcc}
\hline Hook & $\mathbf{N}$ & Symbol & $\begin{array}{c}\text { Opening mean (width) } \\
(\mathbf{m m})\end{array}$ \\
\hline $6 / 0$ & 10 & 1 & $15.6(14.33-16.36)$ \\
$6 / 0$ & 10 & 2 & $15.6(15.39-16.03)$ \\
$4 / 0$ & 10 & 3 & $15.9(15.70-16.35)$ \\
$5 / 0$ & 10 & 4 & $16.8(16.34-17.61)$ \\
$6 / 0$ & 10 & 5 & $18.7(18.42-19.31)$ \\
$8 / 0$ & 10 & 6 & $19.0(18.10-19.48)$ \\
5 & 10 & 7 & $19.9(19.39-20.69)$ \\
$4 / 0$ & 10 & 8 & $21.7(21.54-21.98)$ \\
\hline
\end{tabular}

proportional to the hook size. Due to the simplicity, this is the most employed method.

$$
C *(L)=\frac{C(L)}{N_{d}(L)}
$$

$\mathrm{C}^{*}(\mathrm{~L})=$ relative frequency of retention of individuals with length $\mathrm{L} ; \mathrm{C}(\mathrm{L})=$ number of individuals with length L captured by a certain hook; and $\mathrm{N}_{\mathrm{d}}(\mathrm{L})=$ number of avaiable individuals with length $\mathrm{L} ; \bar{L}=$ mean value of $\mathrm{L}$; $\mathrm{E}=$ constant; and

$\bar{L}=\mathrm{h} * \mathrm{~m}$

where: $\mathrm{h}=$ constant; and $\mathrm{m}=$ hook aperture.

To estimate $\mathrm{E}$ and $\mathrm{h}$, the frequency distribution of length of the individuals captured by different hook sizes were used, in similar conditions.

Let:

$C_{1}(L)=N_{d}(L) e^{-E\left(L-h m_{1}\right)^{2}}$

where: $C_{1}(L)=$ number of individuals with length L captured by time unit using the first hook.

For the second hook, we will have:

$$
C_{2}(L)=N_{d}(L) e^{-E\left(L-h m_{2}\right)^{2}}
$$

Supposing the same $\mathrm{E}$ and $\mathrm{h}$ (for $\mathrm{m}_{1} \approx \mathrm{m}_{2}$ ), we have:

$$
\ln \left(\frac{C_{2}(L)}{C_{1}(L)}\right)=E h^{2}\left(m_{1}^{2}-m_{2}^{2}\right)+2 E h\left(m_{2}-m_{1}\right) L
$$

If we are able to estimate the values of these constants ( $\mathrm{E}$ and $\mathrm{h}$ ), it is possible to adjust data to the selectivity curve.

\section{Results}

In general the capture of Pacu was low and varied among sites. Most of the fish were captured in the River Miranda: 7 in Corumbá, 59 in Bonito and 49 in Miranda; 25 fish were caught in the River Vermelho and 16 in the River Aquidauana, totalling 156 fish caught.

Tables 2 and 3, show that different hook sizes captured individuals of similar size evidenced by similar medians and size overlap. Hook 7 captured smaller individuals than the smallest hook (1). Hook 8 did not capture any specimens and thus was not included in Table 2 . The largest individual was even captured by the smallest hook (Table 3)!

Figure 3 shows the relationships between $\ln \left[\frac{c_{2}(l)}{c_{1}(l)}\right]$ and total length (L) for some hook sizes, for the two sites in the River Miranda (municipalities of Bonito and Miranda). Table 4 presents the coefficient of determination for the hook pairs of contiguous size. There was no significant relationship between $\ln \left[\frac{c_{2}(l)}{c_{1}(l)}\right]$ and total length of captured fishes and the data failed to fit Holt (1963) model. Finally the Kolmogorov-Smirnov test, the results of which are shown in Table 5, did not detect sig- 
Table 2. Total length frequency distribution of pacu caught with different hook sizes in the River Miranda, municipality of Bonito.

\begin{tabular}{|c|c|c|c|c|c|c|c|}
\hline \multirow[t]{2}{*}{$\mathbf{L}(\mathbf{c m})$} & \multicolumn{7}{|c|}{ Number of fish } \\
\hline & Hook 1 & Hook 2 & Hook 3 & Hook 4 & Hook 5 & Hook 6 & Hook 7 \\
\hline $32-34$ & - & - & - & - & - & 1 & - \\
\hline $34-36$ & - & 2 & - & 1 & 1 & 1 & 1 \\
\hline $36-38$ & - & 1 & 1 & 2 & 1 & 1 & 1 \\
\hline $38-40$ & 4 & 2 & 2 & 1 & 2 & - & 2 \\
\hline $40-42$ & - & 3 & 1 & 2 & - & 3 & 1 \\
\hline $42-44$ & 1 & 1 & 4 & 2 & 2 & 3 & 2 \\
\hline $44-46$ & 1 & 2 & 1 & - & - & 1 & - \\
\hline $46-48$ & - & - & 1 & - & - & - & 1 \\
\hline Total & 6 & 11 & 10 & 8 & 6 & 10 & 8 \\
\hline Median & 39 & 41 & 43 & 40 & 39 & 41 & 40 \\
\hline
\end{tabular}

Table 3. Total length frequency distribution of pacu caught with different hook sizes in the River Miranda, municipality of Miranda

\begin{tabular}{lcccccccc}
\hline \multirow{2}{*}{ L $(\mathbf{c m})$} & \multicolumn{7}{c}{ Number of fish } \\
\cline { 2 - 9 } & Hook 1 & Hook 2 & Hook 3 & Hook 4 & Hook 5 & Hook 6 & Hook 7 & Hook 8 \\
\hline $32-34$ & - & - & 1 & - & - & 2 & - & - \\
$34-36$ & 1 & - & - & 1 & - & - & 1 & - \\
$36-38$ & - & - & - & 1 & 1 & 1 & 1 & - \\
$38-40$ & - & 1 & 2 & 2 & 1 & 2 & 1 & - \\
$40-42$ & - & - & 2 & 1 & - & 4 & 1 & - \\
$42-44$ & - & - & - & 4 & - & 5 & 2 & 1 \\
$44-46$ & - & 1 & 1 & - & - & 2 & 1 & - \\
$46-48$ & - & - & - & - & - & 1 & 1 & 1 \\
$48-50$ & - & - & - & - & - & - & - & - \\
$50-52$ & - & - & - & - & - & - & - & - \\
$52-54$ & - & - & - & - & - & - & 1 & - \\
$54-56$ & 1 & - & - & - & - & - & - & - \\
Total & 2 & 2 & 6 & 9 & 2 & 17 & 9 & 2 \\
Median & 45 & 42 & 40 & 41 & 38 & 41 & 43 & 45 \\
\hline
\end{tabular}

Table 4. Pearson coefficient of determination $\left(\mathrm{r}^{2}\right)$ and its p-value for different pairs of hooks according to Figure 3.

\begin{tabular}{llcl}
\hline Hooks & $\mathbf{N}$ & $\mathbf{r}^{2}$ & $\mathbf{P}$ \\
\hline $2 / 1$ & 3 & 0.964 & 0.121 \\
$3 / 2$ & 5 & 0.000 & 1 \\
$5 / 4$ & 4 & 0.057 & 0.761 \\
$6 / 5$ & 3 & 0.942 & 0.154 \\
$3 / 2$ & 2 & - & - \\
$7 / 6$ & 6 & 0.002 & 0.930 \\
\hline
\end{tabular}

nificant differences in the size of captured specimens due to the pronounced size overlap for different hooks.

\section{Discussion}

Capture pattern was not detected among small and large hooks. The lowest number of captures was ob- served in hook 8 , and the reason for that could be its size or its visibility leading fish to avoid it. The length frequency distributions overlap and the low variation in size of captured fishes indicate that differences in selectivity would not be found. Regression results, along with the small size of samples, revealed the non-existence of any relationship between these variables, a primary condition to develop this method. The Kolmogorov-Smirnov test showed that the frequency distributions were similar, i.e., absence of selectivity. Millar (1992) proposed a method to define selectivity based on large samples, high frequencies in each length class, which was not the case in the present study. In some studies, when sample size for a certain gear was very small, data were discarded by the authors (Rodrigues et al., 1983; Puzzi and Silva, 1981; Santos et al., 1976; Mota et al., 1984; Mota et al., 1983; Barthem, 1998). However, it was not clear if they 

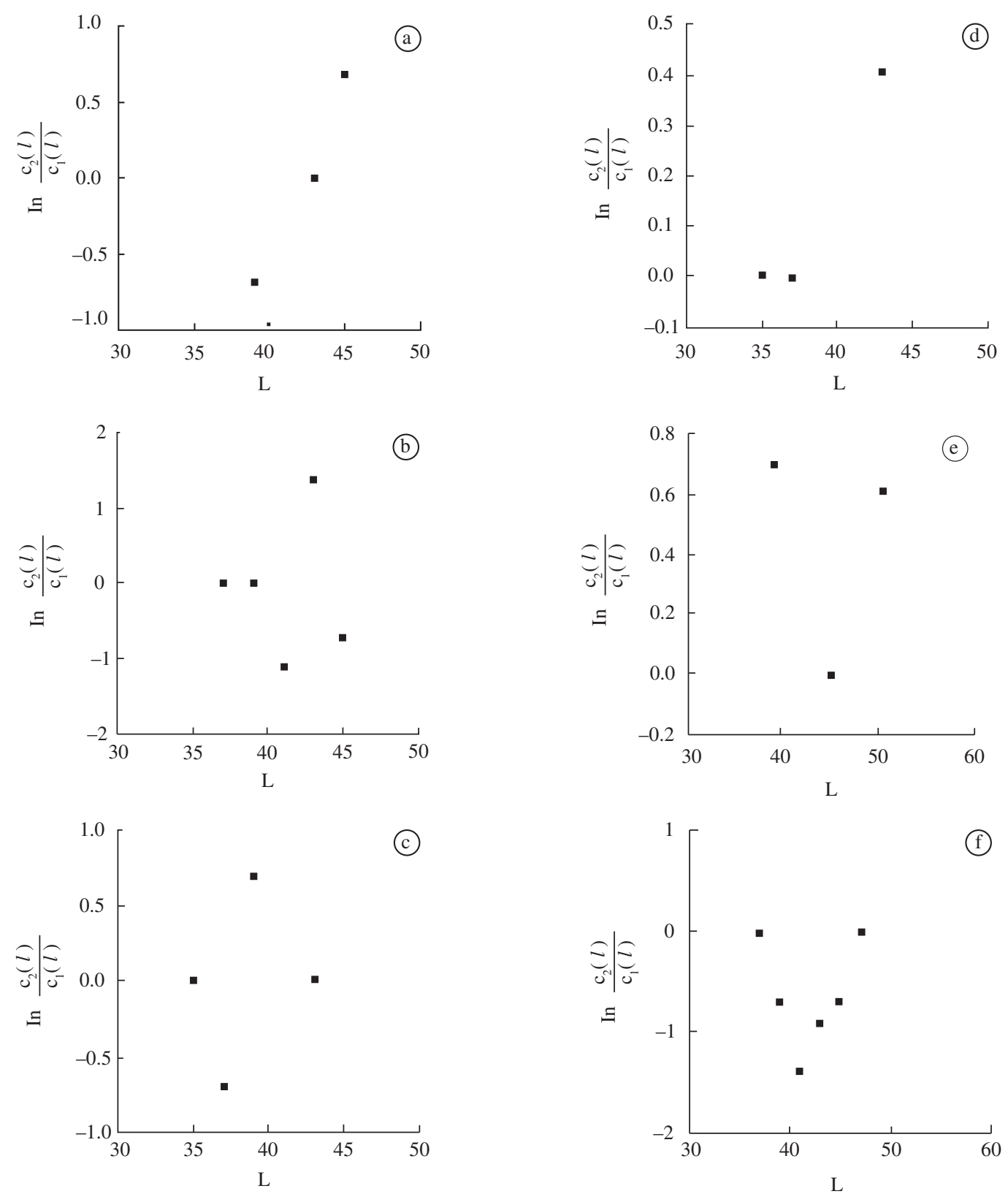

Figure 3. a) Relationship between $\ln \left[\frac{c_{2}(l)}{c_{1}(l)}\right]$ and $\mathrm{L}$ (total length) for hooks 2 and 1 ; b) hooks 3 and 2; c) hooks 5 and 4 ; d) hooks 6 and 5; e) hooks 3 and 2; f) hooks 7 and 6. a,d) Bonito municipality; and e, f) Miranda municipality.

discarded them because there was no relationship between length and capture or for another reason.

If variation in size was low, we can suppose low variation in mouth size, which is a determinant for hook capture. However, this measurement was not taken and we cannot arrive at a conclusion as to whether or not this factor influenced our results. But, according to Millar and Fryer (1999), selection may be intuitively expressed as a function of fish perimeter for mesh apparatus and of fish mouth aperture for hooks. However, length is much easier to measure and is highly correlated with mouth aperture, and it is commonly used in fishing models. Notwithstanding, mouth size may not be the main reason neither the only factor determining hook selectivity. Erzini et al. (1997) studied the relationship between total length and mouth size for six species in order to apply hook selectivity models. These authors found a non-linear significant relationship for three species, suggesting that optimum capture size is not a linear function of hook size. Erzini et al. (1998) also observed a 
Table 5. Kolmogorov-Smirnov (K-S) test comparing the total length frequency distributions for different hook pairs River Miranda (municipality of Bonito). N (number of fish); D statistics of the K-S test; $\mathrm{D}_{\mathrm{c}}$ expected value at $0.05 / 0.01$ probability.

\begin{tabular}{crccc}
\hline Hook pair & $\mathbf{N}$ & $\mathbf{D}$ & $\mathbf{D}_{\mathbf{c}} \boldsymbol{\alpha}=\mathbf{0 . 0 5} / \mathbf{0 . 0 1}$ & \multicolumn{1}{c}{ Decision } \\
\hline 1 & 6 & $18.01(1$ and $)$ & $43 / 54$ & ${\text { Accept } \mathrm{H}_{0}}$ \\
2 & 11 & $36.00(2$ and 3) & $60 / 77$ & ${\text { Accept } \mathrm{H}_{0}}$ \\
3 & 10 & $22.00(3$ and $)$ & $48 / 60$ & ${\text { Accept } \mathrm{H}_{0}}$ \\
4 & 8 & $8.01(4$ and 5$)$ & $34 / 60$ & Accept $\mathrm{H}_{0}$ \\
5 & 6 & $17.98(5$ and 6$)$ & $39 / 45$ & Accept $\mathrm{H}_{0}$ \\
6 & 10 & $10.00(6$ and $)$ & $48 / 60$ & Accept $\mathrm{H}_{0}$ \\
7 & 8 & - & - & - \\
\hline
\end{tabular}

high overlap in capture size frequency distribution and mentioned that this made curve adjustment difficult. The logistic model was used to describe hook selectivity for Diplodus vulgaris, Pagellus acarne, Pagellus erythrinus, and Spondyliosoma cantharus, and according to these authors, this is the most appropriate model for small sized species (maximum total length of $50 \mathrm{~cm}$ in the majority of cases), consequently with low intraspecific variation in mouth size and food habits. In the case of $P$. mesopotamicus, the medians of total length were below the value cited by Erzini et al. (1998) and this could also explain the lack of hook selectivity. Perhaps the failure to fit any selectivity empirical model to our data may be due to the growth of overfishing as larger individuals had already been removed.

Ralston (1990) discusses models developed for trawling and emeshing nets applied to hook selectivity. This author emphasizes that there is no validation of these models and argues that they are very simple. By comparing selection criteria in many fishing gears, Huse et al. (2000) mentioned that fish format in trawling and emeshing nets is a more rigorous selection criterion than those based on competition and behavior, which are important mechanisms for species and size selection in hook fishing. Moreover, comparative captures may not offer conclusive evidence of a selection curve because data adjustment may result in an infinity of selection curve models (Millar, 1995).

According to Millar and Fryer (1999), the inadequate use of size distribution curves, as if they were selectivity curves, has unnecessarily contributed to the increase of divergent opinions regarding the selection curve format for mesh gears and hooks. Until selection curve families for hooks and mesh gears have not been properly developed, few can be deducted from indirect studies with two apparatus of different sizes (Millar, 1992). This author also draws attention to the typical scarcity of large fishes in commercial fishing, which makes it difficult to estimate the correct side of the selection curve, and consequently monotonic curves have been observed.

Huse et al. (1999) studied selectivity in Reinhardtius hippoglossoides and concluded that longline selection process is adaptive: if large and small fishes are present, large ones may dominate the captures. However, if hooks are in an area with homogeneous size distribution dominated by small fishes, then the mechanism leading to selectivity will be much weaker. This could not be the reason for selectivity absence in our study because we believe that size distribution was not homogeneous for small fishes, as adults also occurred at the sample sites.

Lokkeborg and Bjordal (1992) believe that there may be a selection process before fishes find the baits, which exposes a high proportion of large species and individuals to the apparatus. Even without determining selectivity curve for the tested hooks, we expected that large hooks would capture large fishes that can bite the hook, and that small and fragile hooks would not retain large fishes for long periods, or even capture them. The absence of individuals less than $28 \mathrm{~cm}$ in length in the diverse hook sizes probably was related to the fish recruitment process through this apparatus. Capture increases with individuals larger than $32 \mathrm{~cm}$. According to the data collected by Vaz (2001), individuals with these sizes are still in their first year of life.

Ferraz de Lima et al. (1984) determined $34 \mathrm{~cm}$ as the mean total length of P. mesopotamicus females at the first gonadal maturation and above $42 \mathrm{~cm}$, all females were able to spawn. Thus, we conclude that hooks capture individuals that had still not had an opportunity to reproduce. Individuals captured above the minimum capture size according to the current legislation $(45 \mathrm{~cm})$, corresponded to only $14.7 \%$ of the captures. If the mortality of individuals that did not attain the minimum size is high subsequent to release, the adoption of this measure may have not been efficient to allow the renewal of this fish stock and new management measures should be employed in order to protect the species. Harley et al. (2000) concluded that the minimum size may be inadequate in situations where the bycatch mortality is high. These authors also mentioned that the optimum size, estimated from the yield per recruit analysis, may be optimized for a population in equilibrium condition but will not necessarily be favorable to recover a population exploited under non-equilibrium conditions, as is the case of $P$. mesopotamicus. These questions must be taken into account in the management of this species in the Pantanal and strict measures must be adopted in the short term in order to recover its stock. 
Acknowledgments - We are grateful to the Secretaria de Meio Ambiente, Cultura e Turismo de Mato Grosso do Sul for the logistic support during data collection; to CNPq and UNESP for partial financial support; to MUSTAD do Brasil for the fishing material; to Mr. João A. Venturini for the logistic support during the field work, and to Agostinho C. Catella for the help in planning this research.

\section{References}

BARTHEM, R., 1998. Seletividade de rede de emalhar para piramutaba (Brachyplatystoma vaillantii). Bol. Mus. Para. Emilio Goeldi. Sér. Zool., vol. 14, no. 1, p. 5-18.

CATELla, AC. A pesca no Pantanal de Mato Grosso do Sul, Brasil: descrição, nível de exploração e manejo (1994 - 1999). 343p. (Tese Doutorado em Biologia Tropical e Recursos Naturais) - Instituto Nacional de Pesquisas da Amazônia, Universidade do Amazonas, Manaus, 2001.

ERZINI, K., GONÇALVES, JMS., BENTES, L. and LINO, PG., 1997. Fish mouth dimensions and size selectivity in a portuguese longline fishery. J. Appl. Ichthyol., vol. 3, no. 1, p. 41-44.

ERZINI, K., GONÇALVES, JMS., BENTES, L., LINO, PG. and RIBEIRO, J., 1998. Species and size in a "red" sea bream longline "metier" in the Algarve (southern Portugal). Aquat. Liv. Resour, Paris, vol. 11, no. 1, p. 1-11.

FERRAZ DE LIMA, JA. and BARBIERI, G., VERANI, JR., 1984. Período de reprodução, tamanho e idade de primeira maturação gonadal do pacu, Colossoma mitrei, em ambiente natural (River Cuiabá, Pantanal de Mato Grosso), p. 477-497. In Anais do Simpósio Brasileiro de Aquicultura. Anais...3, São Carlos.

GULLAND, JA., 1969. Manual of methods for fish stock assessment: Part 1: Fish Population Analysis. Manuals in Fisheries Science, 4, Rome: FAO.

HAMLEY, JM., 1975. Rewiew of gillnet selectivity. J. Fish. Res. Board Can., Ottawa, vol. 32, no. 11, p. 1943-1969.

HARLEY, SJ., MILLAR, RB. and McARDLE, BH., 2000. Examining the effects of changes in the minimum legal sizes used in the Hauraki Gulf snapper (Pagrus auratus) fishery in New Zeland. Fish. Res., vol. 45, p. 179-187.

HOLT, SJ., 1963. A method for determining gear selectivity and its application, p. 106-115, In The selectivity of fishing gear. Spec. Publ. ICNAF/ICES/FAO. Jt. Sci. Meet., Contrib. S-15, vol. 2, 21p.

HUSE, I., GUNDERSEN, AC., NEDREAAS, KH., 1999. Relative selectivity of Greenland halibut (Reinhardtius hippoglossoides, Walbaum) by trawls, longlines and gillnets. Fish. Res., vol. 44, no. 1, p. 75-93.

HUSE, I., LOKKEBORG, S. and SOLDAL, AV., 2000. Relative selectivity in trawl, longline and gillnet fisheries for cod and haddock. ICES Journal of Marine Science, vol. 57, p. 1271-1282.

LOKKEBORG, S. and BJORDAL, ${ }^{\circ}$ A., 1992. Species and size selectivity in longline fishing: a review. Fish. Res., vol. 13, p. 311-322.

MILLAR, RUSSEL B., 1992. Estimating the size-selectivity of fishing gear by conditioning on the total catch: Aplications and case studies. J. Amer. Statist. Assoc., vol. 87, no. 420, p. $962-968$.

MILLAR, RB., 1995. The functional form of hook and gillnet selection curves cannot be determined from comparative catch data alone. Can. J. Fish. Aquat. Sci., vol. 52, p. 883-891.

MILLAR, RB. and FRYER, ROBERT, J., 1999. Estimating the size-selection curves of towed gears, traps, nets and hooks. Rev. Fish Biol. Fisheries, vol. 9, p. 89-116.

MOTA, A., CAMPOS, EC. and RODRIGUES, JD., 1983. Seletividade em redes de emalhar utilizadas na pesca de acará Geophagus brasiliensis Quoy and Gaimard, 1824 (Osteichthyes, Cichlidae) e época de sua reprodução na represa de Ponte Nova, River Tietê, Estado de São Paulo, Brasil. Bol. Inst. Pesca, vol. 10, p. 119-127.

MOTA, A., RODRIGUES, JD., CAMPOS, EC. and MORAES, MN., 1984. Captura seletiva da Pescada do Piauí, Plagioscion squamosissimus, HECKEL, 1840 (Osteichthyes, Sciaenidae), com redes de emalhar, na represa de Bariri, River Tietê, Estado de São Paulo, Brasil. Bol. Inst. Pesca, vol. 11, p. 13-23.

PEIXER, J., 2003. A seletividade de anzol e o rendimento por recruta do pacu Piaractus mesopotamicus (Holmberg, 1887) no Pantanal de Mato Grosso do Sul, Brasil. (Dissertação Mestrado em Ciências Biológicas) - Universidade Estadual Paulista "Júlio de Mesquita Filho", Rio Claro, 77p.

POPE, J., MARGETTS, AR., HAMLEY, JM., AKYUZ, EF., 1975. Manual of methods for fish stock assessment. Pat III. Selectivity of fishing gear. FAO Fisheries Technology Papers, no. 41, (rev. 1), 46p.

PUZZI, A., SILVA, MRGA., 1981. Seletividade em redes de emalhar e dimensionamento do tamanho de malha para a captura da corvina Micropogonias furnieri (Desmarest, 1823). Bol. Inst. Pesca, vol. 8, p. 139-156.

RALSTON, S., 1990. Size selection of Snappers (Lutjanidae) by hook and line gear. Can. J. Fish. Aquat. Sci., vol. 47, p. 696-700.

RODRIGUES, JD., CAMPOS, EC., MOTA, A., RODRIGUES, NS., 1983. Pesca seletiva do Saguiru, Curimatus gilberti QUOY and GAIMARD 1824 (Osteichthyes, Curimatidae), com a utilização de redes de emalhar, na represa de Ponte Nova, River Tietê, Estado de São Paulo, Brasil. Bol. Inst. Pesca, vol. 10, p. 107-117.

RODRIGUES, AM., RODRIGUES, JD., MORAES, MN. de; FERREIRA, AE., 1988. Curva de seletividade em redes de emalhe utilizadas na captura do saguiru Curimata elegans, Eteindachner, 1875 (Osteichthyes, Curimatidae), na represa de Bariri, River Tietê, Estado de São Paulo, Brasil. Bol. Inst. Pesca, vol. 15 , no. 2, p. 147-154.

SANTOS, EP., MOTA, A. RODRIGUES, JD., 1976. Curva de seletividade em redes de emalhar utilizadas na captura de corimbatá, Prochilodus scrofa (Steindachner, 1881). Bol. Inst. Pesca, vol. 4, no. 4, p. 43-54.

VAZ, MM., 2001. Problemas no ajuste da curva de crescimento do pacu, Piaractus mesopotamicus (Holmberg, 1887) (Pisces: Characidae), e seu manejo no Pantanal Mato-Grossense. (Tese Doutorado em Aquicultura) - Universidade Estadual Paulista, Jaboticabal, 98p. 
